\title{
STATE DEVELOPMENT CORPORATIONS: THE PENNSYLVANIA EXPERIENCE
}

\author{
WilliaM R. DaviIN*
}

Between August 1956 and October 1958, the Commonwealth of Pennsylvania jointly with community nonprofit industrial development corporations, banks, and insurance companies initiated the financing of sixty-eight new manufacturing plants and plant expansions costing $\$ 23,700,000$ and creating Ir,76r new factory jobs, all of them in areas of substantial chronic unemployment. The commonwealth's participation in this financing has been extended through the new Pennsylvania Industrial Development Authority, a public corporation and instrumentality of the state government created by the General Assembly under the Pennsylvania Industrial Development Authority Act. ${ }^{1}$

\section{I}

\section{Historical Background}

Although Pennsylvania enjoys second position among the states in the nation's manufacturing industry, economic history has dealt her some cruel blows. Since the turn of this century, certain industries upon which she has been dominantly dependent have variously experienced readjustments or maladjustments, economically or technologically. As a result, these industries have failed to generate the volume of employment and business opportunities one normally observes in the American economy. In terms of specific areas and and communities and at differing points in time, this has meant either deterioration of the local economic base or failure of the economic base to expand.

For example, lumbering was a major industry for many Pennsylvania areas and communities in the early decades of the century. The philosophy of exploitation that characterized that industry nationally in those years, lack of reforestation and fire control, and the absence of scientific conservation practices have led to depletion of forest resources and a decline of lumbering in many sections.

Textiles were once a major source of employment in a large number of Pennsylvania communities, large and small. The "flight" of textiles to the South from states of the East following and continuing since World War I, and more latterly the expansion of textiles in the South based on the newer synthetic fibers, has meant, again, a partial deterioration of the economic base in affected Pennsylvania communities.

Anthracite coal has been the major single source of employment in the densely-

- Secretary of Commerce, Commonwealth of Pennsylvania; Chairman, Pennsylvania Industrial Development Authority.

${ }^{1}$ PA. STAT. ANN. tit. 73, $\$ \S 30 \mathrm{~T}-\mathrm{I} 4$ (1957). 
populated, topograpically-rugged counties of northeastern Pennsylvania, with virtually all of the nation's "hard coal" coming from that region. The pronounced shift from coal to oil and gas for space-heating that began in the early 1920's has meant a continual secular decline in anthracite markets and employment since that time.

Much of northwestern and western Pennsylvania has, over the years, sustained itself on the mining of bituminous coal. Bituminous coal markets have experienced a growth in line with national economic growth itself. However, the mechanization of deep mines and the growth of surface ("strip") mining has made possible a vastly greater volume of production per man-day and has resulted in a relative decline in manpower requirements.

Over the years, Pennsylvania has developed the largest railway transportation industry of any of the states, transporting her coal and steel and linking together the East, Midwest, and Southeast. A number of Pennsylvania communities and sections of some of her major cities have been dominantly dependent upon railroad maintenance shops. Dieselization of railroads has cut drastically into this source of employment, and the growth of the trucking industry has meant a sharing between railways and truckers of the increase in freight tonnage.

In 1957, Pennsylvania produced just over one-fourth of the nation's steel; that was an increase of about one-third over Pennsylvania's production during World War II. Yet, United States Census Bureau figures indicate that this Pennsylvania production was achieved with some 33,000 fewer steel workers than during the war, thanks to modernization of steel-making processes. ${ }^{2}$

This concatenation of economic phenomena has given Pennsylvania an extensive problem of chronic labor surpluses that, without burdening the reader with statistical detail, can be characterized as follows: ${ }^{3}$

x. While the Pennsylvania pattern of post-World War II unemployment has followed the national pattern, the unemployment rate in Pennsylvania has tended consistently to exceed the national rate; in recession periods, the Pennsylvania rate has reflected an unemployment situation more severe than nationally.

2. As early as the first quarter of 1958 , nationally, seventy major United States Labor Department labor market areas and I2I "smaller" official labor market areas were designated as "Areas of Substantial Labor Surplus" (more than six per cent of the area labor force unemployed). Yet, the ten major Pennsylvania areas made up one-seventh of the national total; the eight of her "smaller" areas in this category made up one-fifteenth of the national total.

3. Nationally, in the first quarter of $195^{8}$, nineteen major labor market areas and fifty-seven "smaller" such areas were classified by the United States Department of Labor as areas of chronic, substantial labor surplus. At the time, Pennsylvania had five-more than one-fourth - of the major areas of chronic unemployment, and seven -about one-eighth-of the smaller areas in this category.

\footnotetext{
${ }^{3}$ See U.S. Bureau of the Census, Dep't of Commerce, U.S. Census of Manupactures: i957.

${ }^{3}$ For details see Hearings Before the House Committee on Banking and Currency on Community Facilities, Area Redevelopment and Small Business Financing Bills, 85 th Cong., 2d Scss. (1958).
} 
These economic vicissitudes provided the stimulus, notably during the years following World War II, for a community industrial development movement in Pennsylvania of considerable magnitude and effectiveness. During those years, some fifty labor-surplus communities, together with their banks, financed 150 manufacturing plants that in prosperous times provide direct employment for 31,000 people; total costs were estimated at $\$ 54,500,000$. The pattern of financing typically used became known outside Pennsylvania through numerous special magazine articles as the "Scranton Plan," since it was in the Scranton area that the movement had its principal origins and most sizable results. Obviously, however, there were many little Scranton plans.

The approach was for local civic groups to finance the full cost of construction, including land and utilities, of plants occupied under lease-purchase arrangements. The "equity" money was typically raised in civic industrial fund "drives," sometimes on a gift basis, at other times in exchange for debentures or other evidence of indebtedness bearing interest. The major financing was typically in the form of first mortgage loans from local banks. Amortization payments by the tenant companies were used fully to retire all funds injected into the projects, with the civic portion frequently going into a community "revolving fund" for reuse.

The new employment opportunities growing out of this "boot-strap" lifting process, however, were inadequate to compensate fully for the declines in employment in dominant industries, nor to stem the downward trend of total employment in distressed economic areas.

II

\section{The Present Program}

The principal element in the present industrial development program was revitalization and professionalization of the state Commerce Department. The Department's personnel was roughly doubled to include some ninety employees, and its industrial development activities were enlarged to embrace research and surveys, technical advisory services and financial assistance to local groups, national advertising, assistance to industrial firms and consulting engineers on plant location surveys, and direct solicitation of out-of-state industry. These services are extended on a state-wide basis, without reference to area unemployment or economic distress. One special tool within the total program, however, is available for use only in areas of chronic labor surplus-Pennsylvania Industrial Development Authority loans.

The Authority's program is a direct outgrowth of the pattern of community industrial financing that has been described. Its principal characteristics were developed in consultation between representatives of the state Commerce Department, on the one hand, and legal and financial specialists from labor-surplus communities that had successfully conducted local industrial financing programs, on the other.

It was the view of both groups that the community experience had proven the efficacy of the financing device employed and that any effort on the part of the 
state government should be projected within that framework; that it should, in other words, supplement and strengthen the community approach to the problem that had already become traditional in labor-surplus communities.

A principal limiting factor in the pre-existent pattern had come to be the difficulty of the local industrial development organization returning too frequently to the public for equity funds. With conventional first mortgages running between fiftyfive and sixty-five per cent of the cost of a given project, the civic organization was left with the necessity of raising thirty-five to forty-five per cent by popular subscription-placing it in competition with the charitable, health, and other "drives" so much a part of community life. Accordingly, it was generally agreed by those in consultation on the matter that the most promising direction for a state effort to take would be to join hands with community groups in sharing the burden of raising the amount required in the pattern for that part of the financing over and above first mortgage funds.

Thus, the central feature of the Pennsylvania Industrial Development Authority program, "the Pennsylvania Plan" or "PIDA," as it is variously referred to, is for the state to provide up to thirty per cent of the cost of new plants or expansions, provided the community group injects at least twenty per cent and arranges for the major financing from private financial institutions. This means, in effect, that the burden of local subscription fund-raising is cut roughly in half, and that funds so raised go twice as far as formerly.

\section{A. The Pennsylvania Industrial Development Authority Act}

The Act creating the Authority recites its purpose as being to promote the welfare of the people of the commonwealth by the reduction of unemployment in "critical economic areas" by making loans to industrial development agencies for the payment of part of the cost of building or acquiring industrial and manufacturing plants and facilities for lease or sale. A board of eleven members is created by the Act to govern the affairs of the Authority. Four serve ex officio: the Secretaries of the Departments of Banking, Labor and Industry, Internal Affairs, and Commerce, the latter serving as chairman and chief executive officer. Seven members are appointed by the Governor for staggered seven-year terms, subject to Senate confirmation; these latter represent "the public and the public interest." The state Commerce Department is directed to provide the staff services of the Authority.

Loans of the Authority may be made only in "critical economic areas," and these are defined as encompassing any municipality or group of counties or region of the commonwealth having had not less than six per cent of its labor force unemployed for a period of not less than three years, or nine per cent for not less than eighteen months, immediately prior to the date of the related investigation by the Authority. Loans of the Authority may be made only to nonprofit industrial development agencies having as their primary function the promotion, encouragement, and de- 
velopment of industrial and manufacturing enterprises. Under the Pennsylvania Constitution, the commonwealth may not lend money to private business firms. ${ }^{*}$

The twenty per cent of the project cost required to be injected by the local nonprofit group and the thirty per cent loan available from the Authority typically leave half of the project cost to be financed otherwise. The Act requires that the local group must have a firm commitment for this financing before the Authority can act favorably on the loan application. Further, under the Act, the plant can be leased only to a "responsible tenant, or sold only to a responsible buyer," and the local group must have a firm commitment from the prospective tenant or buyer to provide the machinery and equipment and occupy and operate the plant. The Act also requires that loans of the Authority shall bear interest, but empowers the Board to set the rates and fix the terms of its loans.

One normally thinks of these loan transactions as involving a new plant or plant addition, with the Authority taking a second mortgage lien on the new construction as security for its loan. But the Act also gives the Authority a second type of loan power that is peculiarly important and pertinent to the community industrial development situation in Pennsylvania.

It has been previously noted that fifty communities had financed $15^{\circ}$ plants, mainly in the years since World War II, prior to establishment of the Pennsylvania Industrial Development Authority. Many of those have since been sold to industrial firms exercising options under lease-purchase agreements. Title to many others, however, is still held by the community groups, and the plants are still in the process of amortization. Of this group, those built during more recent years have substantial balances of principal remaining to be amortized in payments to the community groups (and, of course, also to first mortgage holders). Thus, a community group in many instances will still have funds tied up in a pre-PIDA project in an amount substantially in excess of the twenty per cent required to be injected where PIDA assistance is involved.

In order to release a portion of such previously raised and invested community funds, the Authority is empowered to lend money to the community group, taking as its security a mortgage on the existing plant, provided the proceeds of the loan are used in financing another new project. In these instances, it is required that the community leave at least twenty per cent of the original cost or current appraised value of the plant, whichever is higher, in the project as its continuing investment. This provision has the effect of empowering the Board to assist the community by bringing into the present funds raised by popular subscription in the past and to put such funds to work again in maximizing local industrial employment.

There are two noteworthy provisions of the Act that are in the nature of limitations. First, the Authority may not make a loan where this would cause the removal of a plant from one area of the commonwealth to another. And, secondly, the Authority may not "at any time borrow money or in any manner ... .

- $\mathrm{P}_{\mathrm{A}}$. Const. art. $9, \S 6$. 
pledge the credit or taxing power of the Commonwealth or any of its municipalities or political subdivisions, nor shall any of its obligations be deemed to be obligations of the Commonwealth of any of its political subdivisions." Thus, the Authority is very much the creature of the legislature, since the legislature is the sole source of its capital funds.

The 1955 session of the legislature (in May of 1956 ) appropriated $\$ 5,000,000$ as the initial capital fund of the Authority. Another $\$ 3,000,000$ appropriation was made in 1957, for a total of $\$ 8,000,000$, to date. These monies, under the Act, go into a revolving Industrial Development Fund. Income from interest and loan repayments also go into the Fund and may be used for additional loans.

\section{B. Loan Experience of the Authority}

At the outset of this paper, the highlights of loan operations of the Pennsylvania Industrial-Development Authority since its inception just over two years ago were listed. Fuller details, as of October 3r, r958, follow:

$\begin{array}{lr}\text { Total loan commitments (68 projects) } & \$ 7,917,450 \\ \text { Total cost of projects } & \$ 23,742,260 \\ \text { Estimated annual payroll in projects } & \$ 37,054,500 \\ \text { Planned employment in projects } & \text { II,76I }\end{array}$

It will have been clear, of course, that these figures do not represent the sum of Pennsylvania's industrial growth during the two-year period. These figures are restricted to industrial development projects located in chronic labor-surplus areas in the financing of which community groups, banks and insurance companies, and the commonwealth, through the Authority, have joined hands. In fact, something like four times this amount of new factory employment has developed by virtue of Pennsylvania's new industrial development program outside PIDA financing, whether directly or indirectly.

\section{Interest rates on Authority loans}

In its early deliberations devoted to the setting of operating policies, the Board apprehended its primary obligation to be so to conduct its affairs as to create the maximum of new employment opportunities. Though directed to charge interest on its loans, it did not interpret that direction to require it to make the maximum possible operating profits through such charges. Recognizing that, in accordance with the Act, its loan operations must avoid even the semblance of a "give-away" approach, it has, nonetheless, conceived its discretion as to interest rates to present an opportunity to offer to interested companies a special inducement to locate or expand plants in chronic labor-surplus areas.

It had been, and continues to be, the practice of the participating local industrial development groups to charge an interest item into its transactions on its own portion of the project financing. This has been an obvious necessity when local subscription funds have been raised by evidences of indebtedness bearing interest. This 
practice has been followed, also, where local funds were raised wholly by gift, or through a combination of debt to the citizens and gift. In these latter instances, the local group has, however, enjoyed a latitude under which it could fix its rates lower than might otherwise be the case.

In light of the foregoing, the Authority has established a policy creating a minimum two per cent interest rate on its loans, which it varies in accordance with the community group's interest rate when the latter is between two and three per cent. Where the community is charging in excess of three per cent, the Authority arrives at its own rate after examining the local circumstances involved, always with a view to keeping its own interest rate consistent with the purpose of creating an inducement. The objective of the policy is to persuade the community group to make its interest rate as low as practicable. Low interest rates on half of the project cost (the community's twenty per cent share and the Authority's thirty per cent) mean a significant saving in interest expense to the temant-buyer, and a meaningful inducement.

Interest rates on the first mortgage financing from banks and insurance companies remain, of course, at the going commercial rates.

\section{Repayment of Authority loans}

Having been left free also to set the term of its loans, the Authority has, on the basis of community experience in Pennsylvania with this type of financing, set a maximum term of twenty-five years. In practice, however, the maximum term has seldom been used; most of the Authority's loans are set up for repayment within a period of twenty years and less.

Again, however, by way of enhancing the attractiveness to companies of its financing plan, the Authority early determined that it would, where requested and where other factors seemed to warrant it, defer repayment of its loans until after retirement of the first mortgage in the given case. This practice has the obvious effect of reducing annual amortization charges being paid by companies occupying the plants financed under the plan; while no ultimate saving of principal is involved to the companies, they, nonetheless, have the benefit of reduced expenses in new facilities during the early years of operation, when needs for operating economies and working capital may be primary considerations.

In instances where deferment of repayment of its second mortgage loans has been requested and granted until retirement of the first mortgage, the Authority has stipulated in its loan agreements, again as a matter of established policy, that the interest rate on its second mortgage rises to that of the first mortgage upon retirement of the latter. Since at that point an Authority's loan is in a first mortgage position, enjoying a roo per cent lien on a project in which it has invested only thirty per cent of the cost, such mortgage paper would be attractive to outside investors, provided the interest rate thereon were commensurate with "going" commercial rates. For these reasons, the Authority has anticipated that the Board of Directors 
would then sell its mortgage paper of this type and secure a quick return of its outstanding money into its revolving Industrial Fund.

\section{Plant expansions, branch plants, relocations}

The nature of traditional community industrial financing; in Pennsylvania, coupled with the characteristics of the Authority's loan powers, has enabled it to serve both the out-of-state firm and the established Pennsylvania manufacturer.

Of the sixty-eight Authority loan commitments through October 3r, I958, nineteen have been for the expansion of plants already located and operating in Pennsylvania; five have been for new branch plants of Pennsylvania manufacturers. Of the remaining loan commitments, three are for new plants being built in part with funds borrowed by community groups using previously-financed buildings as security; they are being built in advance of and in order to attract commitments from a manufacturing firm to locate. The twenty-five remaining loans are for projects which involve the relocation of plants from other states; and sixteen are for branch plants of companies from other states. The places of origin of these relocations and branch plants will be of interest. They are as follows:

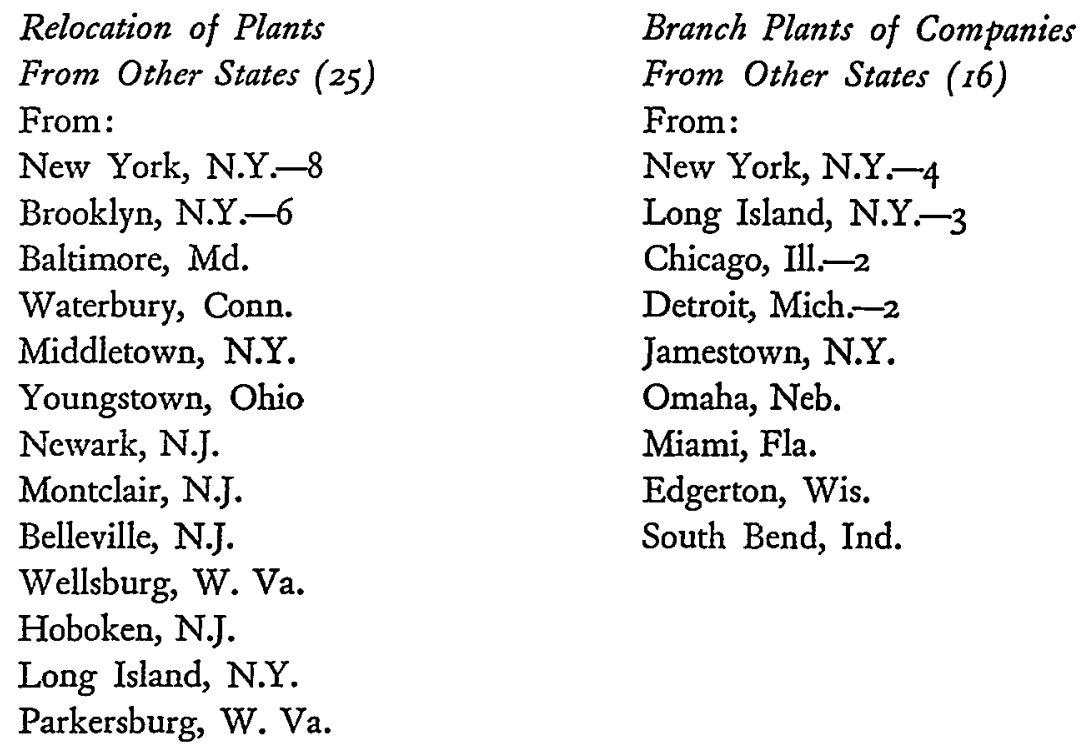

\section{Characteristics of projects financed}

American manufacturing industry is essentially "small business," in the sense that out of the numerical total, the giant steel, chemical, automotive, and heavy industrial equipment firms, for example, are a small minority. The model manufacturing firm is a fabricator or component producer, of one type or other. Thus, in the listing of firms occupying plants financed under the PIDA program, few are nationally-known. Some are, however. The Eberhard Faber Pencil Company, relocated in Wilkes-Barre, Pennsylvania, from Brooklyn in a plant financed in part with PIDA funds, is a 
major national producer in its field. Chrysler occupies a plant for the production of ordnance tank parts at Scranton, similarly financed. Mergenthaler ("Linotype") is to occupy another at Wellsboro; Tetley Tea, still another at Williamsport.

The sixty-eight projects have ranged in size from a building of 8,000 square feet to one of 260,000 square feet; in cost from $\$ 16,800$ to $\$ 2,400,000$. PIDA loans have ranged from $\$ 10,500$ to $\$ 720,000$. Plant employment in the projects has ranged from twenty-five workers to 6oo. Product-wise, the plants include food, postal-canceling machinery, tubular copper products, steel scaffolding, scientific instruments, aluminum building materials, aircraft engine components, commercial chemicals, and garments, in addition to the products noted in the instance of the nationally-known firms listed above.

\section{ConcLusion}

The Pennsylvania Industrial Development program of industrial financing grew directly out of Pennsylvania industrial development experience at the local level. It works effectively in Pennsylvania mainly because it is essentially only an extension of an approach to financing tested and tried at the community level over a period of many years, prior to participation by the commonwealth.

The use of public funds for financing of private industrial activity, at least nonfederal governmental funds, has been and perhaps will for the foreseeable future be questioned on philosophic grounds. It has not been seriously questioned on those grounds in Pennsylvania, and the program has the full support of the business community of the state; banks and insurance companies have entered fully into it with their first mortgage funds.

That this acceptance has been so readily forthcoming is doubtless attributable to the critical need for Pennsylvania to achieve economic redevelopment in its distressed areas. So long as those areas suffer economic decline, they constitute a serious drain on the financial resources of state and local government (through expenditures for unemployment compensation and public assistance, among other things) and a serious wastage of manpower. Pennsylvanians have considered that redevelopment purpose as a valid object for the expenditure of public funds in industrial financing.

From the standpoint of small business, the availability of financing through state and local development corporations can be an important consideration in determining what projects can be undertaken and whether expansion is possible. Indeed, the increasing use of such corporations may be an important factor in the ability of small business to maintain an important position in the national economy. 